\title{
From Winning the Nobel Peace Prize to Leading the Country into Intra-state war
}

\author{
Tsegaye Birhanu \\ Former Lecturer of Political Science at College of Social Sciences and Humanities, Assosa University, Ethiopia \\ DOI: 10.29322/IJSRP.11.09.2021.p11727 \\ http://dx.doi.org/10.29322/IJSRP.11.09.2021.p11727
}

\begin{abstract}
Ethiopia is passing the horrendous time of ethnic war where millions are starving, and hundreds of thousands are either internally displaced or fled to the neighboring countries Putting Ethiopia on the edge of disintegration, the honeymoon of Abiy's administration is over just 2 years after his ascendance to power. This article attempts to shed light on the contemporary humanitarian crisis in Ethiopia. It is based on data collected through interviews and literature reviews from April to July 2021. The rainy season is passing unnoticed in agrarian Ethiopian society where warmongering leaders massively mobilizing civilians to war fronts instead of farm fields. People are changing their plowshares into guns and receiving state-sponsored military training in most parts of the country. This manifestly shows the imminence of more war. In the name of unifying the country, the incumbent regime is in support of expansionist and assimilationist forces in the country. The reported atrocities, ethnic-based massacres, ethnic profiling and harassment, rape of girls and women and massive state-led humanitarian crisis amount to a war crime, making the Nobel prize-winning Prime Minster of Ethiopia a suspect of war crime swiftly in a span of two years. This short article briefly discusses this issue and elaborates what is happening in Ethiopia and how the country can get out of this conflict trap.
\end{abstract}

Index Terms- Ethiopia, Crisis, Abiy, Violence

\section{INTRODUCTION}

$\mathrm{T}$ he brief honeymoon of Abiy Ahmed's administration is over. By the time of writing this article, the country is on the brink of disintegration. After three decades of maintaining relative peace in the turbulent Horn of Africa, Ethiopia is in a crisis of unfolding ethnic war with deteriorating security and human rights situations (Human Rights Watch, 2021). The ethnic war and accompanying atrocities and gross human rights violations reportedly amount to genocide and war crimes swiftly making Abiy Ahmed Ali, the Nobel peace prize winner and the commander in chief of the Ethiopian army, to be suspected of a war crime. At the national level, democracy is in peril, the national election conducted only in parts of the country after several times of postponement was uncompetitive, reportedly below par and overshadowed by the withdrawal of several popular political parties (The Reporter, 8 May 2021). As the seeds of the democracy struggle to germinate in the political landscape of the country, Abiy's alliance with expansionist Amhara Ethno-nationalists immediately started to add a fresh venom to the historical wounds of several ethnic groups in a multi-national Ethiopian state. This is manifestly threatening to tear the country apart.

At the regional level, with Abiy Ahmed's outrageous alliance with Eritrea's dictatorial leader Isaias Afeworki, the conflict in Ethiopia was internationalized with the direct involvement of foreign powers (BBC, 27 January 2021). Sudan, by using the opportunity left by the incapable state apparatus in Addis Ababa busy in dealing with the internal crisis, occupied up to 80 kilometres of land in Ethiopia. On the other hand, initially, the international community was in dilemma of which policy to adopt and what to do regarding Ethiopia. But now, it seems clear that severe sanctions are looming ahead threatening to crumble the aid-dependent economy of the country.

This short piece of writing attempts to shed light on the local, regional and international political contexts that abruptly led Abiy Ahmed from winning a Nobel peace prize to a suspect for a war crime. The article is organized into three sections. The first section deals with his ascendance to power, the honeymoon and early days. The second section is devoted to his later days and the unfolding crisis in the country. The final section will be pinpointing the way forward.

\section{Methodological issues}

This article is produced based on the data collected from primary and secondary sources through key informant interviews and literature review respectively. The key informant interview (KI) was conducted in April and May with scholars and journalists from different ethnic origins. To get a balanced perspective on the contemporary political dynamics of Ethiopia, expatriates engaged in researching Ethiopian politics for over a decade were included in the key informant interviews.

\section{ABIY AHMED's AsCENDANCE TO POWER, THE HONEYMOON AND EARLY DAYS}

Abiy Ahmed assumed political power in 2018 when then Prime Minister Haile Mariam Dessalegn resigned from his position due to waves of violent protest against his regime. With mounting ethno-nationalism, waves of violent protests across different parts of the country against the government started in November 2015 (Amnesty international report (2016). The violent protests initially started as a reaction to the introduction of a new government plan to expand and integrate Addis Ababa city into parts of the surrounding Oromia region (IPSS, 2020). After a new wave of protest led by ethno-nationalist social media activists, the government was forced to cancel the master plan in January 2016 
(Amnesty 2016). Despite the cancelling of the master plan, the protests easily expanded and engulfed other parts of the country, demanding broad socio-economic and political reforms which mobilized the youth (IPSS, 2020). This shows the violent protest was not caused only by the Addis Ababa city's new master plan. In addition to the upsurge of ethno-nationalism and subsequent power struggle, economic inequality, soaring unemployment and rampant corruption remained the underlying factors that can best explain the situation. Since 2017, conflicts have occurred along Somali and Oromia regions displacing over a million people (Amnesty, 2020). In the same year, there was also violent conflict in the Amhara region with the identity question of the Qimant people mounting in a quest for autonomy. The cumulative effect of all these inter-ethnic conflicts and waves of violent protests forced Hailemariam Dessalegn to resign from his power in 2018 (Addis Standard, 15 February 2018). This created a condition for Abiy Ahmed to ascend to power in April 2018.

After Abiy Ahmed's ascendance to power in April 2018, several changes were introduced in the early stages. Immediately after assuming political power, he started to implement "political reforms" to appease the protesting youth. The regime released political prisoners, blacklisted media outlets and political parties previously in exile were allowed to function in the country (Semir, 2019; Amnesty international 2020), at that time no one suspected that he is freeing space in prison for a new round of mass arrest of his new foes. This had, initially, brought a sense of hope across the country helping the regime to get local and international support in 2018 and 2019. Despite the initial positive developments, the new regime manifestly failed to unify the country and bring all political actors on board. The regime's exclusionist approach, the support and alliance it formed with expansionist Amhara ethnonationalists caused a new wave of ethnic-based conflict almost throughout the country.

\section{ABIY AHMED’s LATER DAYS AND THE UNFOLDING CRISIS}

The regime once hailed for massive liberalization and democratization, reacted and swiftly tended to authoritarianism. The tragedy happening in Metekel (Benishangul Gumuz), Tigray and other parts of the country is a microcosm of national political dynamics and the crisis Ethiopia's federation has been facing in the last couple of years. However, the incumbent regime's exclusionist approach, alliance with expansionists and dictators that forced the regime to mobilize all the resources of the country against Tigrian People Liberation Front (TPLF) played significant role. Worryingly, all dissenting ideas raised in different parts of the country were associated with TPLF and used to dump people into prison. His later days were characterized by ethnic wars and postponement of election.

\subsection{The Ethnic Violence and war}

At the time of this study, Ethiopia is indulged in a catastrophic cycle of violence which can even get worse. In 2020 and 2021 the violent inter-ethnic conflict in the country is not showing de-escalation. Evidence reveals that there were exacerbated ethnic conflicts in Benishangul Gumuz, Oromia, Amhara, Somali, Afar and Tigray regions. The Tigray conflict developed into a war between the national government forces and the Tigray regional state forces (Abink, 2021). According to Ethiopian Human Rights Commission (EHRC) report (2020), the war in Tigray has resulted in atrocities that amount to war crime (EHRC, 2020). Amnesty International (2020) reported that in Wellega zone of Oromia ethnic-based killing is a common phenomenon albeit the zone is under military command post. Benishangul Gumuz region in western Ethiopia is also experiencing its worst ethnic-based massacre (Tsegaye, 2020) and people are and will continue starving as the security problems stopped them from accessing their land for next year farming (KI 1, April 23, 2021). Though the Ethiopian National Defence Force (ENDF) controlled the Mekelle City forcing TPLF plight back to the bush (Abink, 2021) after six months the Ethiopian army left Tigray creating enabling environment for the TPLF to control Mekelle again. At the time of writing this article, the conflict has escalated to Amhara and Afar regions.

In response to the exacerbation of inter-ethnic violence and the deterioration of human rights and security issues (Human Rights Watch, 2021), the national government responded by establishing an emergency command post (Amnesty International, 2020). The command post was empowered with imposing curfews, banning meetings and demonstrations, blocking internets, mobile networks and even restricting movements as it deemed necessary for their operation (Ibid). Extrajudicial killings and mass arrests have become common (Amnesty International, 2020). The war in Tigray and in Benishangul Gumuz resulted in hundreds of thousands displaced. In the Tigray war, in addition to ethnic targeted killing and harassment, evidence show that women and girls were raped. The European commission joint statement released on June 10, 2021, stressed that there was "deliberate and repeated hinderance of humanitarian assistance by the military driving the population towards starvation. The statement also indicated that starvation of civilians is being used as a weapon of war" which is against international humanitarian law and jus in bello principles of war. The massive militarization and state sponsored military training manifestly shows the worst is yet to come. Currently, particularly, in Amhara region people are massively arming themselves and receiving state sponsored military training. This is an indication for the imminence of more ethnic violence in the country.

\subsection{The Postponed Election and its results}

Ethiopia has conducted 5 national elections since 1995. After 1991, in principle the country had adopted a multi-party system and conducted periodic elections, however, in reality, Ethiopia remained under dominant party rule for the last three decades (Lyons, 2010). Except for the 2005 election, all the previous elections were characterized by non-competitiveness impacted by either the repression of the incumbent regime or problems within the oppositions themselves (Asnake, 2011; Lyons, 2010). The ascendance of Abiy Ahmed Ali, the world Nobel Peace prize winner for 2019, to power accompanied by his rhetoric for massive democratization and liberalization has created a glimmering sense of hope among the people of the country and beyond (Salih, 2018).

The sixth national election which was initially scheduled to be conducted in August 2020 was postponed twice: first in the name of COVID-19 pandemic (Human Rights Watch, 2021) and second for 'logistic reasons'. The postponement of the national election received different reactions from spectators and political parties. Some opposition parties accepted the postponement and requested for the establishment of a transitional government that 
can run the country until the next election while others considered the postponement as an apparent move of extending tenure for the ruling party (Amnesty international, 2020). The postponement of the election was also blamed by some spectators as a strategy of buying time to further consolidate the newly re-organized ruling party (France 24, 3 May 2021). The ideological and political difference further polarized when the TPLF led regional administration in Tigray rejected the decision of postponing the election and conducted its regional election in September 2020 (Human Rights Watch, 2021). The delayed election conducted only in parts of the country resulted in rubberstamping the incumbent regime.

As ethnic-based conflicts and protests against the government mounted, the regime further narrowed down the political space by even blocking phone and internet communication and arresting opposition leaders (Human Rights Watch, 2021). The reported imprisonment of opposition political leaders, the closing of their offices and the withdrawal of dominant parties from the election (DW, 19 February 2021), overshadowed Ethiopia's democratization. The withdrawal of major political parties from the postponed election by recalling the absence of enabling environment is an indication of the lack of trust in the credibility, freedom, and fairness of the election. Many commentators argued that conducting an election that cannot earn the trust of the Ethiopian public and political actors may result in boiling the ethnic and political tensions into greater violence (KI 3, 27 April 2021; KI 5, 30 April 2021). There is an evolving argument that the narrowing down of political space, particularly, the categorization of the TPLF and OLA as terrorist organizations by the national parliament on 6 April 2021 reveals the presence of more continuities of authoritarianism than changes (KI 7, 3 May 2021).

\subsection{The Reaction of International Community}

Evidence shows that the recent political development occurring in Ethiopia has brough the eyes and ears of the international community back to the often turbulent Horn of Africa. African Union (AU) appointed a special envoy to investigate the situation in Ethiopia in November 2020 (AFP, November 24, 2020). European Union (EU) has also indicated that the block is ready to use all foreign policy tools against "those responsible for human rights violations in Ethiopia" expressing the federal government's denial of the grave humanitarian crisis in the country (Addis standard, March 23, 2021). The union with its joint statement released on 10 June 2021 indicated that war crimes are conducted by the regime where starving people is used as instrument of war. Most recently, different news agencies also reported that the UN security council has conducted a meeting regarding the situation in Ethiopia which ended without agreement among the veto powers. Apart from that many countries including the USA cut their bilateral development aid to Ethiopia (US state department, 23 May 2021) to daunt the government from its action.

The US state department (May 23, 202) announced visa restrictions on Eritrean and Ethiopian officials. Ethiopia receives a lot of foreign assistance and development partners should be careful about how they apply that money (KI 1, April 23, 2021). Sanctions against Ethiopia will not help as there are too many impoverished people in the country that means sanctions punish the poorest (KI 8, 8 May 2021). The international community can also resort to providing more support to the NGOs and CSOs than using the government channels albeit these entities are not immune from maladministration and corruption. The dilemma of the development cooperation community to invest in Ethiopia until there is a different settlement is understandable. A respondent in an interview, recalling governments involvement in a war in the country, further argued that at this time it is very difficult to work with the Ethiopian government which doesn't seem to be committed to the wellbeing of its people (KI 1, 23 April 2021).

\subsection{The Underlining Factors for the Ongoing Crisis in Ethiopia}

The presence of ethnic diversity is not intrinsically a problem. There are countries with highly divided societies living in peace and thriving democracies (Beissinger, 2002; Weber, 2009). On the other hand, there are also mono-ethnic countries dwelling in a quagmire of conflict trap and struggling to install a democratic system. This indicates multi-national nature of the state or diversity perse had never been the main factor for a political problem (Weber, 2009). Historical narratives and the upsurge of ethno-nationalism are important factors. Apart from these, Abiy Ahmed's alliance with dictators in the Horn of Africa and Amhara expansionists has also exacerbated the violence.

\subsubsection{Historical Narratives Inculcating Animosity, Mistrust and Ethnic Rivalry}

There is a lack of agreement, among different actors and the elite, on the past, present and future of the Ethiopian state (KI 7, 3 May 2021). Zahorik (2014) noted that historical narratives were politicized and ethnicized in Ethiopia which has a long history of nationalism and political tension where ethnicity played a remarkable role of mobilizing factor. The contested nature of the history of the country became a subject for contradictory interpretation which some argued moving the country forward needs a new consensus.

The legacy of the power struggle among influential groups (KI 5, 30 April 2021) and the contrasting narrations of Ethiopia have filled the recent debates among academics, elites, and political activists (Zahorik, 2014). This discourse was associated with the Ethiopian state formation which was culminated at the end of the 19th century through conquest and territorial expansion (Markakis, 2011). The contradiction is on what Ethiopia historically was, what it is and what Ethiopia should be in the future (KI 7, 3 May 2021). Is Ethiopia the oldest state in Africa? Who are the three-thousand-year-old Ethiopians? Is Ethiopia a colonial empire by itself? The answers to these questions are contradictory depending upon different views.

Abiy Ahmed's ill designed pan Ethiopianist aspiration and his attempted implementation of the road much travelled by early regimes has resulted him to collide with most political groups in the country.

\subsubsection{The Upsurge of ethnonationalism}

Putting the articulation of the national question and subsequent upsurge of ethnonationalism into perspective needs exploring the erstwhile nation-building strategies. Evidence show that, historically, the evils of marginalization, exclusion and suppression carried out during the assimilationist project in the name of pan-ethiopianism and national unity laid the ground for the emergence of ethno-nationalism as an organizing political principle in Ethiopia (Jalata, 2001; Markakis, 2011). In a similar vein, the continued suppression, the ever-increasing ethnic 
marginalization, identity-based killings and economic inequalities have caused the upsurge of a new wave of ethnic nationalism in post-2015 Ethiopia. This has been the mover and shaker of the contemporary Ethiopian political dynamics.

1.4.3. Abiy Ahmed's Regional coalition with Afeworki

Abiy Ahmed's alliance with Isaias Afeworki of Eritrea and Fermajo of Somalia was considered by most spectators as outrageous move. Though, initially, it awarded Nobel peace prize, the strong personal relationship and consulting Isaias Afeworki was considered as naïve move that forced the country to pay the highest price locally as well as at international level. There are evidence that Afeworki has fully engaged himself in meddling with the internal affairs of Ethiopia, of course, at the invitation of the Prime Minster Abiy Ahmed. Locally, this forced the regime to wage war against TPLF which was a foe for Isaias Afeworki as well. At international level, it led the country to drop unnecessary points in the field of diplomatic relation. The entire west as well as the neighbouring Djibouti and Kenya considered the alliance as unholy that can make the Horn of African region turbulent.

\section{THE WAY FORWARD}

The pathway to peace and deepening democracy in Ethiopia will not be an easy task. There is no simple and immediate solution for Ethiopia's deeply entrenched and complicated problems. Abiy Ahmed's regime successfully failed to figure out how to move the country forward. His approach of allying with local expansionists and regional dictators has only complicated the country's deep entrenched problems. The toxification of political environment that has been happening at the moment has only added a new venom into the old historical ethnic wounds in Ethiopia. Though bailing this country out of quagmire of war needs a fundamental change in the political culture, this article argues that inclusive dialogue that could bring all actors on board, security sector reform and strengthening CSOs will help to move the country forward.

\subsection{Inclusive Dialogue}

The stability of democratization and sustainability of peace depends on the inclusiveness and the ability of the system to integrate all sections of society (Beissenger2002). This important ingredient is lacking in Ethiopia's current political landscape. Abiy's administration excluded important sections like the TPLF unit which had a strong holding in the previous EPRDF leadership that ruled the country for a quarter of a century. As a result, the TPLF leadership withdrew from the ruling coalition as well as from national parliament and other state apparatus putting into question the inclusiveness and legitimacy of the national government (KI 3, 27 April 2021). A transition that could not bring all sections of society and political actors on board will struggle to bring sustainable peace (KI 1, 23 April 2021).

Dialogue and peaceful discussions are the ways to amicably resolve tensions and disagreements. Unfortunately, the government of Ethiopia is holding its stand on not negotiating with other actors. The former Ethiopian prime minister Hailemariam Dessalegn (2020), wrongly recalling the impunity and immoral nature of negotiating with rogue actors, argued that an internationally brokered deal with TPLF would result in power sharing. According to Dessalegn (2020), this severely harms the cause for justice and sustainable peace. The point he missed here is, will the war serve justice and sustainable peace? I would say no. Evidence also shows that despite the war fought for several months neither of the conflicting parties achieved their goal; instead, new problems and issues emerged further complicating the conflict dynamics (Addis Standard, 8 May 2021). But negotiation and dialogue might have at least prevented the publicly reported atrocious killings, rape and displacement.

The window of opportunity for dialogue and peaceful negotiation seems lost and gone when the national parliament endorsed a council of misters' resolution designating the TPLF and Oromo Liberation Army (OLA) as terrorist organizations on 7 May 2021 (The Reporter, 8 May 2021). This article argues the ruling party, government and all other actors should believe in negotiation, dialogue, and peaceful resolution of conflicts. CSOs and other actors should work on developing a culture of reasoned and civilized discussion instead of resorting to violence which is deadly by its nature in the country (KI 6, 30 April 2021).

\subsection{Security Sector Reform}

Max Weber identified that monopoly control of means of violence is the foundation of the state and its capacity to govern effectively (Acemoglu and Robinson, 2013). In Ethiopia, at the moment, the monopoly control of means of violence is at risk. There are different armed military units at different levels commanded by different centers in the country. At the national level, there are the national defense force and the federal police. On the other hand, all the 10 regional states have their own strong paramilitary, known as the special forces (The Reporter, 2 January 2021).

Assessment of the legal grounds for the establishment of this security force reveals its unconstitutional nature. The federal constitution in its article 52 that defined the powers and functions of the regional states granted the right to the states "to establish and administer a state police force and maintain public order and peace within the state" (FDRE constitution, 1995, article 52). That means the federal constitution only allows regional states to have a police force, not a para-military force (KI 6, 30 April 2021). Hence the establishment of this paramilitary (special force) is not in line with the provisions of the FDRE constitution (KI 1,

23 April 2021).

The genesis of establishing special forces dates to the early 2010s when the Somali region special force was established (The Reporter, 2 January 2021). The aim of establishing the Somali regional state paramilitary or special force was to curb the insurgent Ogaden National Liberation Front (ONLF) (KI 1, April 23, 2021). However, establishing special force proliferated throughout all regions in the country. Even the recently established Sidama regional state inaugurated its first batch of special forces 2 months after the establishment of the region (The Reporter, 2 January 2021). This has drained monopoly control of physical violence, impacting peace and development in Ethiopia. First, the establishment of these paramilitaries brought an arms race among the regional states with news of recruitment, training and inauguration broadcasted by the regional and national media outlets (The Reporter, 2 January 2021; KI 8, 8 May 2021).

Secondly, since 2018 these forces were used by the respective regional states against either the Ethiopian National Defence Force (ENDF) or another regional force on different occasions. The reported involvement of the Tigray and Amhara special forces in the war in Tigray, the frequent clashes between the Afar and Somali special forces (The reporter, 2 January 2021) 
are worth mentioning. The deadliest war has been occurring in Tigray between the Tigray special force, later become Tigrian Defence Force and ENDF since 4 of November 2021 which resulted in reported deaths of thousands and displacement of hundreds of thousands (EHRC, 2020; Human Rights Watch, 2021).

Generally, in the absence of monopoly control of physical means of violence, it will be difficult for the government of Ethiopia to effectively govern this vast country. Restoring peace and order and deepening democracy in the country needs revamping the security sector and ensuring monopoly control of means of violence in the country.

\subsection{Strengthening CSOs}

CSOs can play important role in reducing violence, building sustainable peace and serving as watchdogs which enhances accountability (Paffenholz, 2009; Ewald, 2013). In the presence of open political space, CSOs can play this role in Ethiopia. The worst thing is in the last two years the political space narrowing down in Ethiopia. As a result, CSOs in the country are not in a position to play their role. A respondent to an interview further argued that

The closing down of the democratic space again over the last one and a half years indicates that and particularly today after the war in Tigray from the 4th of November everyone keeps quiet. Civil societies which are there are intimidated and timid and don't say anything against the terrible atrocities happening. They are not to influence politics at the policy level. They are working at the lower level with development projects but they don't have the capacity, resources, to serve as peace stabilizing or conflict mitigating actors.

\section{(KI 7, 3 May 2021)}

The incumbent regime should open the political space so that CSOs can play an advocacy role in promoting peace and democracy in Ethiopia.

\section{CONCLUSION}

The brief honeymoon of Abiy Ahmed's administration is over. Abiy Ahmed, once considered as the right leader to save this ancient, uncolonized country from disintegration is, unfortunately, leading the country in the wrong direction with a clear danger of tearing the country apart. His journey from receiving applauds across the world and winning the Nobel prize in October 2019 swiftly changed to condemnation and suspect of war crime in early 2021.

At the moment, Ethiopia is passing horrendous time of internal ethnic war. The violent Ethnic conflict is unfolding throughout the country which developed into open war. This is dominantly a result of the incumbent administration's exclusive political approach that failed to bring all political actors on board. The atrocities and gross human rights violations happening in Ethiopia reportedly amount to genocide and war crime. Under the mask of unifying the country, Abiy Ahmed's approach of allying with local expansionists and regional dictators has only complicated the second most populous African state's deep entrenched problems. In addition to that, his regime's toxification of political environment has added a new venom into the old historical ethnic wounds in Ethiopia. At this time all the hopes that united Ethiopians during Abiy Ahmed's ascendance to power has evaporated leaving the country on the verge of disintegration.

\section{REFERENCES}

[1] Addis Standard (5 February 2018) Ethiopia PM Hailemariam Desalegn resigns. Accessed on 15 April 2021 at https://addisstandard.com/breakingethiopia-pm-hailemariam-desalegn-resigns/

[2] Addis Standard (8 May 2021) The Case for Ceasefire, Dialogue and Reconciliation in Tigray: Why And How?. Accessed 10 May 2021 at https://addisstandard.com/opinion-the-case-forceasefire

[3] Addis Standard (March 23, 2021) EU "Ready to Activate All Foreign Policy Tools" Against Human Rights Violations in Tigray; to Dispatch Envoy Back to Ethiopia. Accessed on March 24, 2021 at https://addisstandard.com/newseu-ready-to-activate-all-foreign-policy-tools-against-human/rightsviolations-in-tigray-to-dispatch-envoy-back-to-ethiopia

[4] Acemoglu, Daron and James Robinson (2013) The Monopoly of Violence: Evidence from Colombia. Journal of the European Economic Association. Vol 11 PP 5-44 Accessed on 12 May 2021 at https://scholar.harvard.edu/files/jrobinson/files/monopoly_of_violence.pd

[5] Agence France Press, November 24, 2020. Accessed on March 18, 2021 at https://www.msn.com/enus/news/world/un-security-council-holds-firstmeeting-on-ethiopia-s/Tigray

[6] Ewald, Jonas (2013). "Challenges for the Democratization Process in Tanzania: Moving Towards Consolidation after 50 Years of Independence". Mkuki na Nyota publishers

[7] Human Rights Watch (2021) World report: Ethiopia. Accessed on 11 May 2021 at https://www.hrw.org/world-report/2021/country-chapters/ethiopia

[8] Institute for Peace and Security Studies (2020) Ethiopia Conflict Insight. Peace and Security Report. Volume 1. Accessed on 26 April, 2021 at https://media.africaportal.org/documents/Ethiopia/Conflict-Insights-Vol-13042020.pdf

[9] Salih, Mohammed, Andrea Eshete and Samuel Assefa (2018). "Reflections on Expanding Ethiopia's Political Space: Aspirations, Opportunities and Choices". Friedric Erbet Stiftung: Addis Ababa Office. Accessed at http://fes-ethiopia.org/wp-content/uploads/2020/05/Reflectoinon/Expanding-Ethiopias-Democratic-Space.pdf

[10] Semir, Yesuf (2019) Drivers of ethnic conflict in contemporary Ethiopia. Monograph 202. Accessed on March 23, 2021 at https://issafrica.s3.amazonaws.com/site/uploads/mono-202-2.pdf

[11] The Reporter (8 May 2021) House endorses designation of TPLF, Shene as Terrorist groups. Accessed on 12 May 2021 at https://www.thereporterethiopia.com/article/house-endorses/designationtplf-shene-terrorist-gro

[12] BBC (27 January 2021) Ethiopia's Tigray crisis: US calls for Eritrea troops to withdraw. Accessed on 12 May 2021 at https://www.bbc.com/news/worldafrica-55825560

[13] Zahorik, Jan (2014) Colonial Perspective and Nationalism(s) in Ethiopia in the Context of African Decolonization. Department of Historical Sciences, Faculty of Philosophy and Arts, University of West Bohemia in Pilsen. Accessed at https://www.academia.edu/31652148/

[14] Tsegaye, Birhanu (2020) The Murky Politics Behind the Metekel Massacres. Ethiopia Insight. Accessed at https://www.ethiopiainsight.com/2020/12/29/the-murky-politics-behind-the-metekel-massacres/

[15] Paffenholz, Thania (2009) Civil Society and Peacebuilding. CCDP Working Paper. Accessed on 8 May, 2021 at https://repository.graduateinstitute.ch/record/4060\#record-files-collapseheader

[16] Dessalegn, Hailemariam (2020) Ethiopia's Government and the TPLF Leadership Are Not Morally Equivalent. Foreign Policy. Accessed on April 25, 2021 at https://foreignpolicy.com/2020/11/24/ethiopia-tigray-war-endftplf-abiy-ahmed-federal/government-not-morally-equivalen

[17] Jalata, Assefa (2001) Ethno-nationalism and the global modernizing project Nations and nationalism. Vol 7, no 3 pp 385-405 accessed on April 10, 2021 at https://www.deepdyve.com/lp/wiley/ethno-nationalism-and-the-globalmodernising-project/TOKCOHEJR

[18] Markakis, John (2011) Ethiopia the last two frontiers. Eastern Africa Series: James Currey.

[19] Weber, Anke (2009) The Causes of Politicization of Ethnicity: A Comparative Case Study of Kenya and Tanzania. Center for Comparative and International Studies, ETH Zurich. Working Paper No 47 accessed on 27 April, 2021 at https://www.files.ethz.ch/isn/109603/WP_47_Weber_Politicization_final.p df 
[20] Beissinger, Mark (2008) A New Look at Ethnicity and Democratization. Journal of Democracy. Volume 19, Number 3 pp. 85-97. accessed on April 1, 2021 at https://muse.jhu.edu/article/241801

[21] DW February 19, 2021. OLF offices closed and members arrested. Accessed

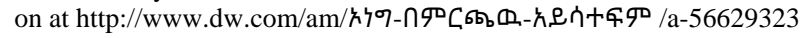

[22] France 24 (3 May 2021) Which way for Ethiopia? Abiy cracks down on regional revolts ahead of elections. Accessed on 3 May 2021 at https://www.youtube.com/watch? $\mathrm{v}=608 \mathrm{VNDi} 2 \mathrm{SdM}$

[23] Asnake, Kefale (2011). "The Unmaking of Opposition Coalitions and the Challenges of Democratization in Ethiopia 1991-2011". Journal of Eastern African Studies. Vol 5, No 4. Accessed on March 22, 2021 at https://www.tandfonline.com/doi/abs/10.1080/17531055.2011.642525

[24] Lyons, Terrence (2010) Ethiopian Elections: Past and Future. International Journal of Ethiopian Studies. Vol. 5, No. 1 pp. 107-121 accessed on April 21, 2021 at https://www.researchgate.net/publication/262090287

[25] EHRC (2020) Ethiopian Human Rights Commission: Rapid Investigation into Grave Human Rights Violation in Maikadra Preliminary Findings, 24 November 2020. Accessed on 11 May 2021 at
https://www.horndaily.com/wp-content/uploads/2020/11/MaikadraPreliminary-Findings/English-Final.pd

[26] Amnsty International (2020) Beyond Law Enforcement Human Rights Violations by Ethiopian Security Forces in Amhara and Oromia. Accessed on 25 April $\quad 2021$ at https://www.amnesty.org/download/Documents/AFR2523582020ENGLIS H.PDF

\section{AUTHORS}

First Author - Tsegaye Birhanu, Former Lecturer of Political Science at College of Social Sciences and Humanities, Assosa University, Ethiopia, e-mail tsgpsir@yahoo.com 